Annuaire suisse de politique de développement

8 | 1988

Annuaire Suisse - Tiers Monde 1989

\title{
Femmes et développement : trois exemples
}

Frauen als Entwicklungsträgerinnen: drei Beispiele

\section{Elfie Schöpf}

\section{OpenEdition}

\section{Journals}

Édition électronique

URL : http://journals.openedition.org/aspd/1295

DOI : $10.4000 /$ aspd. 1295

ISSN : 1663-9669

\section{Éditeur}

Institut de hautes études internationales et du développement

\section{Édition imprimée}

Date de publication : 1 décembre 1988

Pagination : 193-201

ISSN : 1660-5934

\section{Référence électronique}

Elfie Schöpf, «Femmes et développement : trois exemples », Annuaire suisse de politique de

développement [En ligne], 8 | 1988, mis en ligne le 13 mars 2013, consulté le 08 septembre 2020. URL : http://journals.openedition.org/aspd/1295 ; DOI : https://doi.org/10.4000/aspd.1295

Ce document a été généré automatiquement le 8 septembre 2020

(c) The Graduate Institute I Geneva 


\section{Femmes et développement : trois exemples}

Frauen als Entwicklungsträgerinnen: drei Beispiele

\section{Elfie Schöpf}

\section{NOTE DE L'ÉDITEUR}

En français, résumé seulement. Lire l'article original en allemand dans Schweizerisches Jahrbuch für Entwicklungspolitik : « Frauen als Entwicklungsträgerinnen : drei Beispiele ", http://sjep.revues.org/1095. 